
analysis of predictors

\title{
Transtorno de estresse pós-traumático em vítimas de acidentes rodoviários graves: análise de fatores preditores
}

\author{
Tânia Sofia Fernandes Pires'1, Ângela da Costa Maia ${ }^{1}$ \\ ${ }_{1}$ Centro de Investigação em Psicologia, Escola de Psicologia, Universidade do Minho, Portugal. \\ Instituição onde o trabalho foi elaborado: Universidade do Minho, Campus de Gualtar, Braga, Portugal.
}

Received: 12/11/2012 - Accepted: 9/2/2013

\begin{abstract}
Background: Motor vehicle accidents (MVA) are traumatic experiences that are related to psychological disorders as posttraumatic stress disorder (PTSD). Peritraumatic dissociation and acute stress disorder (ASD) have been studied as predictors of PTSD. Studies have also found that women report more psychological symptoms after traumatic experiences than do men. Objective: Analyze the explanatory contribution of peritraumatic dissociative experiences, ASD symptoms and gender toward the subsequent development of PTSD. Method: One hundred twenty-four male and female victims of serious MVA were evaluated at the hospital ( $\mathrm{t} 1$ ) and four months after the MVA ( $\mathrm{t} 2$ ). Participants completed a peritraumatic dissociative experiences questionnaire (PDEQ) ( $\mathrm{t} 1$ ), a questionnaire used to evaluate ASD (SASRQ) ( $\mathrm{t} 1$ ) and a traumatic event scale (RTES) used to evaluate PTSD (t2). Results: Of the studied population, 64.5\% report ASD (t1) and 58.9\% report PTSD (t2). Peritraumatic dissociation and ASD symptoms are positively correlated with PTSD symptoms. Females report more peritraumatic dissociation, ASD and PTSD than do males. Peritraumatic dissociation, ASD and gender (female) explain $26.8 \%$ of the observed variance in PTSD symptoms (t2), with gender contributing only marginally to the model. Discussion: A high rate of MVA victims report PTSD, and peritraumatic responses predict the subsequent development of PTSD, suggesting the need to consider these predictors in methods for the prevention of psychopathology.
\end{abstract}

Pires TSF, Maia AC / Rev Psiq Clín. 2013;40(6):211-4

Keywords: Motor vehicle accidents, peritraumatic dissociation, ASD, PTSD, gender.

\section{Resumo}

Contexto: Os acidentes rodoviários são acontecimentos potencialmente traumáticos que podem originar transtornos psicológicos, designadamente transtorno de estresse pós-traumático (TEPT). Os estudos são controversos quanto ao poder preditivo da dissociação peritraumática e os sintomas de transtorno de estresse agudo (TEA) para predizer TEPT, mas referem que as mulheres reportam mais sintomas de transtorno pós-exposição traumática. Objetivo: Analisar o contributo da dissociação peritraumática, dos sintomas de TEA e do gênero para predizer TEPT quatro meses após o acidente. Método: Cento e vinte e quatro homens e mulheres, vítimas de acidentes graves, avaliados no hospital (t1) e reavaliados quatro meses depois (t2). Resultados: Entre os participantes, 64,5\% apresentam TEA (t1) e 58,9\%, TEPT (t2). Os sintomas de dissociação peritraumática e TEA correlacionam-se positivamente com os sintomas de TEPT. As mulheres reportam mais dissociação peritraumática, TEA e TEPT. A dissociação peritraumática, o TEA e o gênero (feminino) explicam $26,8 \%$ da variância de TEPT, sendo o contributo do gênero marginalmente significativo. Conclusões: O número de vítimas com sintomas de TEPT após acidente grave é elevado e os sintomas peritraumáticos são preditores de TEPT, sugerindo a necessidade de considerar os sintomas iniciais na prevenção de transtorno posterior.

Pires TSF, Maia AC / Rev Psiq Clín. 2013;40(6):211-4

Palavras-chave: Acidentes rodoviários, dissociação peritraumática, TEA, TEPT, gênero.

\section{Introduction}

Motor vehicle accidents (MVA) are a life event with the potential to affect the global population. The World Health Organization (WHO) considers MVA one of the leading causes of death in people 24 years old and younger ${ }^{1}$. It is estimated that every year 1.2 million people die of injuries sustained through motor vehicle accidents². In Brazil, MVA are the eighth leading cause of death, particularly among individuals 20 to 39 years old ${ }^{3}$. Aside from mortality, MVA result in a variety of negative consequences: physical injuries, changes in familial functioning and professional performance, changes in social relations and other costs stemming from the legal and economic implications of $\mathrm{MVA}^{4-6}$. Along with the impact of motor vehicle injuries on physical health, MVA result in mental health costs, particularly those resulting from dissociative responses, acute stress disorder (ASD) and posttraumatic stress-disorder (PTSD).

Peritraumatic dissociation is characterized by distortions in time perception, bodily awareness and spatial awareness during and immediately after exposure to a traumatic event ${ }^{7}$, and peritrau- matic dissociation is reported to be common among MVA victims. According to Barton et al. $834 \%$ to $57 \%$ of MVA victims report symptoms associated with peritraumatic dissociation. Current data are inconclusive regarding the predictive power of peritraumatic dissociation in the development of PTSD. Studies conducted with MVA victims show that peritraumatic dissociation predicts PTSD $^{9-12}$, which is consistent with the results of a meta-analysis ${ }^{13}$. However, a recent systematic review ${ }^{14}$ found that peritraumatic dissociation does not always predict PTSD. The characteristics of participant, the instruments used in the study and methodological issues have been proposed to justify data diversity and the difficulty in generalizing the relationship between peritraumatic dissociation and PTSD from the reported results.

Acute stress disorder (ASD) is an immediate response to a traumatic event. ASD is assessed by the presence of three or more dissociative symptoms and symptoms of re-experiencing, avoidance and activation. Symptoms must persist for a minimum of two days to four weeks after the traumatic exposure to be indicative of $\mathrm{ASD}^{15}$. 
Such symptoms have been reported in between 13\% and 21\% of MVA victims $^{16-19}$. Those MVA victims who report initial ASD tend to report subsequent PTSD 16,18,20. Holeva et al. ${ }^{18}$ found that, among those who report initial ASD, the probability of experiencing PTSD three to six months after the accident increases 20 -fold; other research ${ }^{16,21}$ has shown that ASD symptoms explain $33 \%$ of the variance in the occurrence of PTSD months after an accident.

Post traumatic stress disorder (PTSD) can be present after actual or threatened death, physical injury, or other threats to the physical integrity of the self or others ${ }^{15}$. The diagnosis of PTSD requires the presence of one or more re-experience symptoms, three or more avoidance symptoms and two or more activation symptoms, and PTSD may last for more than a month after the traumatic event ${ }^{15}$.

The prevalence of PTSD in MVA victims varies. Norris ${ }^{21}$ found PTSD in $11 \%$ of studied MVA victims. Other authors have reported different values at different times. During the first months after an accident, rates of PTSD vary between $16 \%$ and $41 \%{ }^{22,23,24}$; data from evaluations performed four months after an accident are approximately $40 \%{ }^{25}$ and when evaluation is conducted six months after an accident, rates of PTSD range from $6 \%$ to $26 \% 16,17,26$. Twelve months after MVA, rates of PTSD range from $2 \%$ to $30 \%{ }^{23,27}$, and two years after the same event, the rate of PTSD in MVA victims is approximately $20 \%{ }^{16,17}$.

One variable that has been considered in the literature as a potential predictor of psychological disorder after MVA is gender. Some studies believe that gender differences in psychological responses after MVA exist, and these studies point to the fact that women demonstrate psychological disorder more frequently than men, particularly ASD 28 and PTSD28-30.

The literature suggests that PTSD occurs very frequently in MVA victims, but there is some controversy about peritraumatic dissociation and the predictive power of ASD on PTSD. The samples studied tend to include victims with and without severe injuries and do not account for accident severity, which could explain the inconsistent results obtained. In this study, we only included victims of serious MVA, to assess the diagnosis of ASD days after MVA, to evaluate the diagnosis of PTSD four months later and to analyze the predictive power of peritraumatic dissociation and ASD symptoms to explain later psychological disorder (PTSD). Another limitation observed in the literature is the lack of control over predictive variables when the contribution of gender to peritraumatic dissociation, ASD and PTSD is assessed. Our hypothesis is that women report more peritraumatic dissociation, more ASD and more PTSD than do men. We are also interested in whether gender contributes to the observed variance in reported PTSD after controlling for other variables.

Only victims of serious MVA were included in this study. According to the literature, we expected high rates of ASD and PTSD; we also hypothesized that peritraumatic dissociation and ASD symptoms evaluated days after MVA would predict PTSD four months after MVA. We had an additional exploratory hypothesis about gender; we expected that, after controlling for responses immediately after MVA (peritraumatic dissociation and ASD symptoms), gender adds variance to the predictive model of PTSD.

\section{Method}

\section{Participants}

Participants included 124 victims of serious MVA admitted to hospital following their accidents: $27.4 \%$ were women $(\mathrm{N}=34)$, and $72.6 \%$ were men $(\mathrm{N}=90)$. All participants were between the ages of 18 and $65(\mathrm{M}=34.49, \mathrm{SD}=13.78)$. Within the sample, $54 \%$ were single, $41.1 \%$ were married and $4.8 \%$ were divorced.

\section{Measures}

Peritraumatic Dissociative Experience Questionnaire (PDEQ4; Portuguese version from Maia, Horta-Moreira, and Fernandes,
200931). This questionnaire contains 10 items rated on a 5-point Likert scale ( $0-4$ points), has good internal consistency $(\alpha=.87)^{31}$ and is significantly associated with traumatic stress response measures, the degree of exposure to stress and other measures of psychopathology. In our research, PDEQ has good internal consistency $(\alpha=.81)$.

Stanford Acute Stress Reaction Questionnaire (SASRQ ${ }^{32}$; Portuguese version from Pires and Maia, 2007). SASRQ contains 30 items rated on a six-point Likert scale. The questionnaire assesses psychological symptoms experienced during the four weeks after exposure to traumatic events. The questions assess dissociative symptoms (10 items), re-experience symptoms (6 items), avoidance symptoms (6 items), arousal symptoms (6 items) and deterioration of functioning ( 2 items). The results range between 0 (zero) and 150 points. Studies of the original instrument when using the total score showed good internal consistency ( $\alpha$ between .80 and .95) ${ }^{32}$. In this study, we also used the total score and found that it indicated good internal consistency $(\alpha=.75)$.

Response to Traumatic Event Scale (RTES, McIntyre \& Ventura, 1996) ${ }^{33}$. This scale contains 17 dichotomous items that allow the diagnosis of PTSD according to DSM-IV criteria (APA, 2002). The scale is organized into three subscales: re-experiencing (5 items), avoidance ( 7 items) and arousal (5 items). The totaled results of the scale range from 0 to 17 points ${ }^{33}$. Studies with maltreated adolescent victims showed good reliability, content validity and internal consistency $(\alpha=.71)^{34}$. In the present study, we found that the scale possessed good internal consistency $(\alpha=.87)$.

\section{Procedure}

This study was approved by the ethics committees of hospitals in the north of Portugal. We made the first contacts with victims (t1) in the hospital an average of five days after their MVA. In this initial contact, we explained the study procedures and objectives, ensured data collection confidentiality and obtained written informed consent from those who agreed to participate. Twenty-three MVA victims did not agree to participate claiming fears of reprisals by employers and insurers, fears of conflicts with the police or unavailability.

The subjects who agreed to participate were contacted by telephone four months after their initial evaluations ( $\mathrm{t} 2$ ), and we ensured free collaboration as well as the confidentiality and anonymity of the data we collected.

\section{Data analysis}

Statistical analysis were performed with Statistical Package for the Social Sciences (SPSS) version 20.0. To identify the percentage of participants with ASD and PTSD, descriptive statistical procedures were run. The criteria for normality were not satisfied, so we used non-parametric statistical tests. To analyze the relation between symptoms of peritraumatic dissociation, ASD and PTSD, we performed correlational analysis (Spearman Rho). To identify gender differences in symptoms of peritraumatic dissociation, PTSD and ASD, we used the Mann-Whitney test. To analyze PTSD predictors, we used a hierarchical regression analysis.

\section{Results}

\section{Dissociative symptoms, ASD and PTSD symptoms}

Considering their total scores on the scales used, at baseline (t1), participants reported a mean of 15.31 symptoms of dissociation (SD $=10.148)$ and a mean of 12.38 symptoms of ASD (SD = 7.258). Of the participants, $64.5 \%$ reported symptoms consistent with a diagnosis of ASD. Four months after the MVA (t2), the mean of PTSD symptoms was $8.77(\mathrm{SD}=4.44)$, and $58.9 \%$ of participants met the criteria for PTSD diagnosis. 
Relationship between peritraumatic dissociation, ASD and PTSD

Correlational analysis between peritraumatic dissociation, PTSD and ASD indicated that participants with more peritraumatic dissociation reported more ASD symptoms $\left(\mathrm{r}_{\mathrm{sp}}=.619, p<.01\right)$ and more PTSD symptoms $\left(\mathrm{r}_{\mathrm{sp}}=.407, p<.01\right)$; participants who reported more ASD symptoms at baseline tended to report more PTSD symptoms four months after the MVA $\left(\mathrm{r}_{\mathrm{sp}}=.460, p<.01\right)$.

\section{Sex differences in symptoms}

Women reported more peritraumatic dissociation symptoms and more ASD and PTSD symptoms than did men (Table 1).

Table 1. Differences in peritraumatic dissociative responses, ASD and PTSD symptoms by gender $(\mathrm{N}=124)$

\begin{tabular}{|l|c|c|c|}
\hline & \multicolumn{2}{|c|}{ Mean range } & $\begin{array}{c}\text { Mann- } \\
\text { Whitney Test }\end{array}$ \\
\hline & Men & Women & Z \\
\hline Peritraumatic dissociation & 57.91 & 74.66 & $-2.23^{*}$ \\
\hline ASD symptoms (total score) & 53.34 & 86.75 & $-4.52^{* *}$ \\
\hline PTSD symptoms (total score) & 55.74 & 80.38 & $-3.43^{* *}$ \\
\hline
\end{tabular}

${ }^{*} p<.05 ;{ }^{* *} p<.01$.

\section{Predictors of PTSD}

To test the contribution of immediate responses on symptoms occurring four months later, we analyzed the power of peritraumatic dissociation and ASD to predict PTSD.

Hierarchical regression analysis data (Table 2) indicated that peritraumatic dissociation and ASD symptoms explain $24.6 \%$ of the variance in PTSD and that both had significant betas (step 1). After controlling for the effects of these variables, we found that gender (step 2) added 2.2\% to the explained variance, resulting in a marginally significant contribution to the prediction of PTSD. The final model explained $26.8 \%$ of the variance in PTSD symptoms $\left(\mathrm{F}_{3,12}=14,679, p<.001\right)$.

\section{Discussion}

Portuguese reports of MVA indicate that men are more frequently involved in accidents than are women, a scenario that has been maintained over time ${ }^{35,36}$ and is reflected in this study, as the majority of our participants are men.

As expected, we observed a high percentage of victims of serious MVA with ASD symptoms several days after the accident (t1) and with PTSD symptoms four months later (t2). At $\mathrm{t} 1,65 \%$ of MVA victims met the criteria for ASD diagnosis, and at $\mathrm{t} 2,59 \%$ met the criteria for PTSD diagnosis. These results are higher than those reported by Blanchard et al. 37,38 , which could be explained by the fact that, in this study, participants were exclusively victims of serious MVA. The perception of danger and threat to life in the moment of the accident and the severity of the injuries sustained have been shown to be predictors of PTSD after MVA ${ }^{39}$ because these factors can interfere with victims' daily routines for long periods of time.

We found that women report more psychological symptoms than do men, particularly peritraumatic dissociation symptoms, ASD symptoms and PTSD symptoms, as previous studies have also shown $28,30,40,41$. Differences between men's and women's responses to trauma were found in other types of experiences as well ${ }^{42}$, and these may be related to gender differences in psychophysiological responses to stress, in the perception of threats, in coping strategies and in social support ${ }^{43}$. However, the literature also suggests that there are risks associated with the presence of PTSD symptoms in women ${ }^{44}$. Differences in peritraumatic dissociative responses between genders have been considered important in the explanation of the higher rates of PTSD in women ${ }^{45}$, which led us to control for this variable. However, our results suggest a low specific contribution of gender to the observed variance in PTSD symptoms.

The contributions of peritraumatic dissociation and ASD symptoms to PTSD are similar to those previously reported in review articles ${ }^{19,46}$ and meta-analyses ${ }^{13,47}$ that underline the important relation between peritraumatic dissociation and subsequent symptoms, arguing that dissociation is the best predictor of PTSD ${ }^{13}$, in contrast to other studies that have not found this relationship ${ }^{14}$.

This study replicates data found in the literature on MVA psychological consequences and PTSD predictors and extends these results by only including victims of serious MVA. We believe that these data are important in practical health settings and suggest that professionals be aware of potential risk factors that increase the rate of development of PTSD symptoms. We believe that prevention can improve the quality of health services and the quality of life of victims of serious MVA.

This study contributes to the ongoing analysis of the psychological impact of serious MVA, but it has some limitations, including the reduced sample size used, the fact that some measures used are not adapted to the Portuguese population and its failure to analyze the predictive power of the severity of the accident. We only assessed psychological disorders (ASD and PTSD) as predictive factors in victims of serious MVA. Future studies should include MVA victims with varying accident severities to analyze whether severity has a moderating effect on psychological disorders. In this study, only 34 women participated, which may explain the marginally significant contribution of gender to PTSD symptoms. This leads us to encourage care in the analysis of data and in generalization from its results. Additional studies should be conducted to analyze the implications of this study for clinical and health practice on the level of prevention and intervention to improve the quality of life of victims of serious MVA.

Table 2. Hierarchical regression to predict PTSD (four months after MVA)

\begin{tabular}{|c|c|c|c|c|c|c|}
\hline Step & & $\mathrm{R}^{2}\left(\mathrm{R}_{2} \mathrm{adj}\right)$ & $\Delta \mathrm{R}^{2}$ & $\beta$ & $\mathrm{T}$ & $\mathrm{F}$ \\
\hline 1 & Peritraumatic dissociation & $.246(.234)$ & .246 & .227 & $2.248^{*}$ & $19,767^{* *}$ \\
& ASD symptoms (total score) & & & .321 & .236 & $2.173^{* *}$ \\
\hline 2 & Peritraumatic dissociation & $.268(.250)$ & .022 & .249 & $2.322^{*}$ & $14.679^{* *}$ \\
& ASD symptoms (total score) & & & -.164 & $-1.908^{*}$ & \\
& Gender & & & & \\
\hline
\end{tabular}

${ }^{*} p<.05 ;{ }^{* *} p<.01 ;+p<.10$.

\section{References}

1. World Health Organization. Mortality from road traffic injuries in children and young people. European Centre for Environment and Health. 2007; Fact Sheet no 2.1 .
2. World Health Organization. Road traffic injuries: a new WHO project. Online Journal of The Bridge Quarterly Newsletter of WHO/EUROPE. Spring 2008, 21.

3. Ribeiro SF, Góes JR. Road accidents in Brazil. IATSS Research. 2005;29(2):68-70. 
4. Haldu A. Psychological Analysis of Road Traffic Accident in Africa: a case study of Nigeria. In: Proceedings of the VIIth World Congress of the International Road Safety Organisation; 1996 June 15-16; Budapest, Hungary; 1996. p. 97-101.

5. Magalhães T. Estudo tridimensional do dano corporal: lesão, função e situação (sua aplicação médico-legal). Almedina; 1998.

6. Walker E, Newman E, Koss A. Costs and health care utilization associated with traumatic experiences. In: Schnurr P, Green B, editors. Trauma and health consequences of exposure to extreme stress: Washington DC: American Psychological Association; 2003. p. 43-69.

7. Marmar C, Weiss D, Metzler T. The Peritraumatic Dissociative Experiences Questionnaire. In: Wilson J, Keane T, editors. Assessing Psychological Trauma and TEPT: The Guilford Press; 1997. p. 412-28.

8. Barton K, Blanchard E, Hickling E. Antecedents and consequences of acute stress disorder among motor vehicle accident victims. Behav Res Ther. 1996;34:805-13.

9. Briere J, Scott C, Weathers F. Peritraumatic and persistent dissociation in the presumed etiology of TEPT. Am J Psychiatry. 2005;162:2295-301.

10. Pires T. Perturbação de stress pós-traumático em vítimas de acidentes rodoviários [dissertation]. University of Minho, Braga; 2005.

11. Ursano R, Fullerton C, Epstein R, Crowley B. Peritraumatic dissociation and posttraumatic stress disorder following motor vehicle accidents. Am J Psychiatry. 1999;156:1808-10.

12. Zoellner L, Jaycox L, Watlington C, Foa E. Are the dissociative criteria is ASD useful?. J Trauma Stress. 2003;16:341-50.

13. Ozer E, Best S, Lipsey T, Weiss D. Predictors of posttraumatic stress disorder and symptoms in adults: a meta-analysis. Psychol Bull. 2003;129:52-73.

14. Velden $P$, Witmann $L$. The independent predictive value of peritraumatic dissociation for TEPT symptomatology after type I trauma: a systematic review of prospective studies. Clin Psychol Rev. 2008;28:1009-20.

15. American Psychological Association. Manual de Diagnóstico e Estatística das Perturbações Mentais - texto revisto. Lisboa: Climepsi; 2002.

16. Bryant R, Harvey A. Relationship of acute stress disorder and posttraumatic stress disorder following mild traumatic brain injury. Am J Psychiatry. 1998;155:625-9.

17. Harvey A, Bryant R. Predictors of acute stress following motor vehicle accidents. J Trauma Stress. 1999;12:519-25.

18. Holeva V, Tarrier N, Wells A. Prevalence and predictors of acute stress disorder and TEPT following road traffic accidents: thought control strategies and social support. Behav Ther. 2001;32:65-83.

19. Bryant R. Does dissociation further our understanding of PTSD? J Anxiety Disord. 2007; 21:183-91.

20. Murray J, Ehlers A, Mayou R. Dissociation and post-traumatic stress disorder: two prospective studies of road traffic survivors. Brit J Psyquiatry. 2002;180:363-8.

21. Norris F. Epidemiology of trauma: frequency and impact of different potentially traumatic events on different demographic groups. J Consult Clin Psychol. 1992;60(3):409-18.

22. Delahanty DL, Raimonde AJ, Spoonster E, Cullado M. Injury severity, prior trauma history, urinary cortisol levels, and acute PTSD in motor vehicle accident victims. J Anx Disord. 2003;17:149-64.

23. Ehlers A, Mayou R, Bryant R. Psychological predictores of chronic posttraumatic stress disorder after motor vehicle accidents. J Abnorm Psychol. 1998;107:508-19.

24. Zatzick D, Kang S, Muller H, Russo J, Rivara F, Katon W, et al. Predicting posttraumatic distress in hospitalized trauma survivors with acute injuries. Am J Psychiatry. 2002;159:941-64.

25. Blanchard E, Hickling E, Mitnick N, Taylor A, Loos W, Buckley T. The impact of severity os physical injury and perception of life threat in the development of post-traumatic stress disorder in motor vehicle accident victims. Behav Res Ther. 1995;33:529-34.

26. Wrenger M, Lange C, Langer M, Heuft G, Burgmer M. Psychiatric disorders after an accident: predictors and the influence of the psychiatric condition prior to accident. Eur Psychiatry. 2008;23:434-40.
27. Koren D, Arnon I, Lavie P, Klein E. Sleep complaints as early predictors of posttraumatic stress disorder: a 1 - year prospective study of injured survivors of motor vehicle accidents. Am J Psychiatry. 2002;159:855-7.

28. Bryant R, Harvey A. Gender differences in the relationship between acute stress disorder and posttraumatic stress disorder following motor vehicle accidents. Aust N Z J Psychiatry. 2003;37:226-9.

29. Fullerton C, Ursano R, Epstein R, Crowley B, Vance K, Kao T, et al. Gender differences in posttraumatic stress disorder after motor vehicle accidents. Am J Psychiatry. 2001;158:1486-91.

30. Coronas R, Pare G, Viladrich C, Santos J, Menscho J. Clinical and sociodemographic variables associated with the onset posttraumatic stress disorder in road traffic accidents. Depress Anxiety. 2008;25:E16-23.

31. Maia A, Horta-Moreira S, Fernandes E. Adaptação Portuguesa do Questionário de Experiências Dissociativas Peritraumáticas (QEDP) numa amostra de bombeiros. Rev Psiq Clín. 2009;36:1-9.

32. Cardeña E, Koopman C, Classen C, Waelde L, Spiegel D. Psychometric properties of the Stanford Acute Stress Reaction Questionnaire (SASRQ): a valid and reliable measure of acute stress. J Trauma Stress. 2000;13:719-34.

33. McIntyre T, Ventura M. Escala de Avaliação de Resposta ao Acontecimento Traumático: versão Adolescentes [Response to Traumatic Event Scale]. In: Almeida LS, Araújo S, Gonçalves MM, Machado C, Simões, MR. Avaliação Psicológica: Formas e Contextos. Braga: Apport; 1996; IV. p. 567-76.

34. Alberto I. Perturbação de stress pós-traumático e suas consequências psicológicas em crianças e adolescentes vítimas de maltrato [dissertation]. Faculdade de Psicologia e Ciências da Educação da Universidade de Coimbra; 1999.

35. Autoridade Nacional de Segurança Rodoviária. Principais indicadores de sinistralidade rodoviária - Relatório Anual de Sinistralidade Rodoviária 2009. Portugal: Observatório de Segurança Rodoviária; 2010.

36. Autoridade Nacional de Segurança Rodoviária. Principais indicadores de sinistralidade rodoviária - Relatório Anual de Sinistralidade Rodoviária 2010. Portugal: Observatório de Segurança Rodoviária; 2011.

37. Blanchard E, Hickling E, Mitnick N, Taylor A, Loos W, Buckley T. The impact of severity os physical injury and perception of life threat in the development of post-traumatic stress disorder in motor vehicle accident victims. Behav Res Ther. 1995;33:529-34.

38. Blanchard E, Hickling E, Barton K, Taylor A, Loos W, Jones-Alexander J. One-year prospective follow-up of motor vehicle accident victims. Behav Res Ther. 1996;34:775-86.

39. Mayou R, Ehlers A, Bryant B. Posttraumatic stress disorder after motor vehicle accidents: 3 -years follow-up of a prospective longitudinal study. Behav Res Ther. 2002;40:665-75.

40. Fullerton C, Ursano R, Epstein R, Crowley B, Vance K, Kao T, et al. Gender differences in posttraumatic stress disorder after motor vehicle accidents. Am J Psychiatry. 2001;158:1486-91.

41. Irish L, Fischer B, Fallon W, Spoonster E, Sledjeski E, Delahanty D. Gender differences I PTSD symptoms: an exploration of peritraumatic mechanisms. J Anxiety Disord. 2011;25(2):209-16.

42. Serafim A, Saffi F, Achá M, Barros D. Dados demográficos, psicológicos e comportamentais de crianças e adolescentes vítimas de abuso sexual. Rev Psiq Clín. 2011;38:143-7.

43. Olff M, Langeland W, Draijer N, Gersons B. Gender in posttraumatic stress disorder. Psychol Bull. 2007;133(2):183-204.

44. Quitete B, Paulino B, Hauck F, Aguiar-Nemer A, Fonseca V. Transtorno de estresse pós-traumático e uso de drogas ilícitas em mulheres encarceradas no Rio de Janeiro. Rev Psiq Clín. 2012;39:43-7.

45. Irish L, Fischer B, Fallon W, Spoonster E, Sledjeski E, Delahanty D. Gender differences in PTSD symptoms: an exploration of peritraumatic mechanisms. J Anxiety Disord. 2011;25(2):209-16.

46. Hart O, Ochten J, Son M, Steele K, Lensvelt-Mulders G. Relations among peritraumatic dissociation and posttraumatic stress: a critical review. J Trauma Dissociation. 2008;9:481-505.

47. Lensvelt-Mulders G, Hart O, Ochten J, Son M, Steele K, Breeman L. Relations among peritraumatic dissociation and posttraumatic stress: a metaanalysis. Clin Psychol Rev. 2008;28:1138-51. 